\title{
Penyuluhan Optimalisasi Pendapatan Ekonomi Rumah Tangga dengan Memanfaatkan Media Online di Masa Pandemi
}

\author{
Asti Gumartifa*, Nadia Afrilliana, Lesi Agusria, Dita Adawiyah, Anggreany Hustia \\ Fakultas Ekonomi dan Bisnis, Universitas Muhammadiyah Palembang, Palembang, Indonesia
}

\section{Article history}

Received: 28-09-2020

Revised: $20-10-2020$

Accepted: 24-10-2020

*Corresponding Author:

Asti Gumartifa,

Fakultas Ekonomi dan Bisnis, Universitas Muhammadiyah

Palembang, Palembang,

Indonesia;

Email:

asti.gumartifa.ump@gmail.com
Abstract: In the Pandemic of Covid -19, Indonesia had a lot of changes that have occurred in society and other circles. Types of changes that occur for example; the process of teaching, learning activities and office in offline or in other words work from home. The economic income also has decreased as well as the household economic income of residents in each region. The existence of Internet facilities can greatly assist all groups of society in facing the transition of change in carrying out every work activity, and schools that usually done at home. By utilizing the Internet and computers as technology in the use of social media which is facilitated by the internet therefore the public can continue to carry out economic activities online. As the existence of social media, the community still be able to carry out in buying and selling activities to get profit and improve the household economy. The example of social media that also can be used are; instagram, facebook, whats up, and e-mail. Thus, from the use of social media, it still can help family economy income to be existed during the Pandemic of Covid -19 .

Keywords: Internet; Technology; Media; Income; Economics

Abtrak: Dalam Pandemic Covid -19 di Indonesia memiliki banyak sekali perubahan yang terjadi pada masyarakat di semua kalangan. Jenis-jenis perubahan yang terjadi contohnya; proses kegiatan belajar mengajar serta perkantoran yang dilakukan offline atau work from home, pendapatan ekonomi negara yang menurun, serta pendapatan ekonomi keuangan menurun begitu juga dengan pendapatan ekonomi rumah tangga warga di setiap daerah-daerah. Adanya fasilitas Internet sangatlah dapat membantu semua kalangan masyarakat dalam menhadapi adanya transisi perubahan dalam melaksanakan setiap kegiatan pekerjaan, dan sekolah secara biasanya hanya saja dilakukan dirumah. Dengan memanfaatkan Internet dan Komputer sebagai teknologi dalam penggunaan media social yang difasilitasi oleh internet masyarakat dapat tetap melakukan kegiatan ekonomi secara online. Dengan adanya media social masyarakat tetap dapat melaksanakan kegiatan jual beli untuk mendapatkan keuntungan dan meningkatkan perekonomian rumah tangga. Adapun media social yang dapat di gunakan yaitu; instagram, facebook, whats up, dan e-mail. Sehingga, dari pemanfaatan media social tersebut tetap dapat membantu perekonomian keluarga tetap berjalan di masa pandemic Covid -19 ini.

Kata Kunci: Internet; Teknologi; Media; Pendapatan; Ekonomi 


\section{PENDAHULUAN}

COVID-19 (Coronavirus) merupakan penyakit coronavirus versi baru yang yang dapat menular. Penyakit muncul pada akhir tahun lalu tepatnya pada bulan Desember 2019. seseorang yang terinfeksi virus COVID-19 memiliki keluhan pernapasan sedikit hingga parah. Penyakit ini dapat dikatan menjadi penyakit yang mematikan namun ada juga yang mengalami kesembuhan paska terinfeksi penyakit ini tanpa obat obatan. Pada individu usia lanjut dan yang memiliki riwayat masalah medis seperti kardiovaskular, diabetes, penyakit pernapasan kronis, dan kanker akan lebih cenderung mudah terinfeksi virus COVID-19 (Yuliana, 2020).

COVID-19 sangatlah meresahkan pada masyarakat yang terjadi pada akhir 2019 di Wuhan, China. Virus tersebut telah menyebar ke 203 negara, dengan kasus terkonfirmasi sejumlah 827.419 dengan angka kematian 40.777 jiwa. Indonesia tidak lepas dari COVID-19 yang mengakibatkan banyak korban yang meninggal dunia. Tentunya langkah terbaik sudah dilakukan, dan hal tersebut didukung oleh kontribusi media sosial sebagai edukasi masyarakat tentang penanganan dan pencegahan COVID-19 (Papdi Forum, 2020). Saat ini semua pemerintah serta layanan masyarakat telah berperan aktif dalam meminimalisir peninggkatan angka penularan Covid -19.

Pemanfaatan media sosial sangan memberikan fasilitas kepada seluruh masyarakat dalam memberikan arahan untuk mencegah penularan COVID-19. Dalam kenyataannya terdapat beberapa faktor dari adanya media sosial yang mempengaruhi kegiatan masyarakat dengan kesadaran dalam membuat perubahan kegiatan keseharian pada masyarakat. Dengan adanya teknologi computer dan Internet dapat memberikan informasi kesehatan untuk menjaga kesehatan individu maupun masyarakat agar terhindar dari COVID-19 (Papdi Forum, 2020). Masyarakat juga telah harus siap dalam pola fikir atau konsep untuk melanjutkan perekonomian baik secara individu maupun dalam lingkup yang luas. Komunikasi dengan memanfaatkan teknologi dalam menggunakan aplikasi media social merupakan dasar strategi promosi penjualan yang diterapkan agar dapat memberikan dampak positif bagi pendapatan masyarakat Warpindyastuti dan Sulistyawati (2018). Media sosial memiliki jangkauan untuk dapat memberikan informasi kepada masyarakat secara luas. Media sosial juga dapat memengaruhi perilaku individu untuk dapat menerapkan kegiatan jual beli dengan tetap menerapkan prilaku yang patuh akan protocol kesehatan.

Internet merupakan gabungan jaringan komputer yang merupakan satu kesatuan dan dapat membaca serta menguraikan komunikasi tertentu. Internet juga merupakan sebuah spesifikasi sederhana mengenai bagaimana komputer dapat berinteraksi satu sama lainnya. Dari Internet telah menciptakan berbagai macam media social. Internet memiliki banyak fungsi dalam kehidupan sehari hari. Dengan adanya pemanfaat penggunaan media social dalam kegiatan penjualan, masyarakat tetap dapat memperoleh pendapatan perekonomian rumah tangga di masa Pandemic Covid -19. Masyarakat dituntut untuk siap dan faham bagaimana hidup di zaman 4.0 dimana semuanya menerapkan teknologi dalam setiap kegiatan. Seiring dengan perkembangan teknologi terdapat banyak sekali macam aplikasi dan sarana jual beli yang dapat digunakan oleh masyarakat dalam memperoleh keuntungan dalam setiap kegiatan. Misalnya saja fasilitas Internet yang menciptakan berbagai macam social media yang masing-masingnya memilki fitur fitur kelebihan.

Pada pemanfaatan social media dalam bidang jual beli seperti Lazada, Shopee, Blibli.com, Buka Lapak yang dapat juga dipromosikan melalui What's up, Facebook, E-mail dan Instagram saat ini sedang menjadi tren di kalangan masyarakat. Tentunya dalam pengaplikasian media social tersebut sangat dibutuhkan wawasan yang luas untuk dapat mengoptimalkan penggunaan dalam kegiatan jual 
beli dimasa Pandemic Covid -19. Masyarakat tetap dapat melakukan kegiatan berdagang dengan menggunakan media social tersebut sesuai dengan target penjualan masing-masing. Sehingga walaupun masyarakat terkenadala dalam kegiatan promosi jual beli, masyarakat tetap dapat menggunakan atau memanfaatkan media social secara optimal.

Adapaun fasilitas positif yang dimiliki dari media social adalah dapat memberika fitur-fitur informasi dan komunikasi secara luas (Situmorang, 2012). Komunikasi tersebut dapat dimanfaatkan masyarakat untuk megembangkan perekonomian rumah tangga dengan cara saling melakukan kegiatan jual beli dengan cara menginformasikan barang atau dagangan yang dapat mereka jual untuk menambah pendapatan perekonomian rumah tangga pada masyarakat.

Saat pandemi COVID-19 ini masyarakat harus menempatkannya perubahan struktur sosial secara keseluruhan. Hal ini juga terjadi khususnya pada warga masyarakat kelurahan Talang Keramat yang merupakan mitra tempat kami melaksanakan PKM. Banyaknya keluhan masyarakat mengenai kurangnya pendapatan yang dikarenakan Pandemi Covid -19 Saat ini. Adanya fasilitas internet berpotensi untuk membantu individu baik pasien COVID-19 dan masyarakat umum dalam meningkatkan perekonomian rumah tangga. Secara khusus, intervensi media sosial memiliki beberapa keuntungan, termasuk aksesibilitas yang luas serta bisa menjangkau batasan.

Oleh karenanya, media sosial tidak hanya menawarkan berjuta informasi yang ada di dalamnya, namun menuntut kedewasaan dan kematangan berpikir penggunanya. Dengan dampak kuat dari media dalam membentuk proses sosialisasi dan perilaku orang-orang, dapat dikatakan bahwa media adalah kekuatan yang kuat dalam membentuk identitas nasional dalam pandemi COVID-19 ini. Masyarakat menggunakan media sosial untuk berbagi pendapat, mencari informasi, dan berbagi cerita tentang pengalaman mereka, serta melakukan peningkatan ekonomi rumah tangga (Purbohastuti, 2017).

\section{METODE}

Pengabdian masyarakat ini dibuat untuk menjelaskan gambaran gambaran umum, klasifikasi, dan proses pengaplikasian dari alat atau media social yang sangat familiar di era Global saat ini. Penelitian ini tergolong penelitian kualitatif. Dengan kata lain, pengabdian masyarakat ini memberikan informasi gambaran tentang teoritis dari manfaat penguaan aplikasi yang ada di media sosial. Tujuan dari pengabdian masyarakat ini adalah untuk memberikan pemahaman tentang manfaat yang dapat diperoleh dari fasilitas media social. Selain itu, penelitian ini juga menyebutkan step atau cara pengoperasian untuk tiap-tiap aplikasi media social yang sangat familiar.

Kegiatan pengabdian masyarakat dilakukan dengan memaparkan tujuan dari diselenggarakannya kegiatan pengabdian kepada masyarakat kepada pihak mitra. Kegiatan ini bertujuan agar nantinya pihak mitra dapat lebih mengoptimalkan penggunaan digital teknologi informasi dari perangkat mobile yang dimiliki untuk lebih mengoptimalkan kegiatan usaha yang dilakukan. Sehingga dengan memanfaatkan digital teknologi informasi kegiatan usaha yang dilakukan dapat meningkatkan keuntungan, pangsa pasar yang semakin meluas, jumlah penjualan meningkat dan biaya pemasaran dapat diminimalisir. Dalam kegiatan pengabdian masyarakat di masa Pandemi Covid 19 ini dilakukan secara offline, dimana kegiatan dilakukan dengan mengumpulkan pihak mitra untuk hadir ke kantor Lurah Talang Keramat. Dari pertemuan tersebut dipaparkan mengenai tujuan, alur dan segala hal yang akan dilakukan dalam pelaksanaan kegiatan pelatihan. 
Pengabdian masyarakat ini diharapkan berkontribuasi positif terhadap kemajuan ilmu pengetahuan di bidang pengabdian kepada masyarakat baik lisan maupun tertulis. Rekomendasi yang dihasilkan yaitu berupa pendekatan yang intens pada masyarakat untuk dapat megetahui lebih jelas apa sajakah dan bagaimana meningkatkan perekonomian rumah tangga dengan maksimal dengan upaya penggunaan dari media sosial.

\section{HASIL DAN PEMBAHASAN}

Dalam pelaksanan kegiatan pelatihan dipaparkan beberapa materi yang kaitannya dengan mengoptimalkan penggunaan perangkat smartphone dalam mendukung peluang bisnis di masa pandemi Covid 19. Beberapa materi yang dipaparkan diantaranya: 1) Fungsi HP Android secara umum; 2) Media sosial sebagai media promosi; 3) Aplikasi Shopee online shop sebagai media untuk memulai berbisnis bagi ibu rumah tangga; 4) mengoptikalkan penggunaan whatsapp. Berikut ini adalah dokumentasi pada saat pengabdian masyarakat berlangsung.
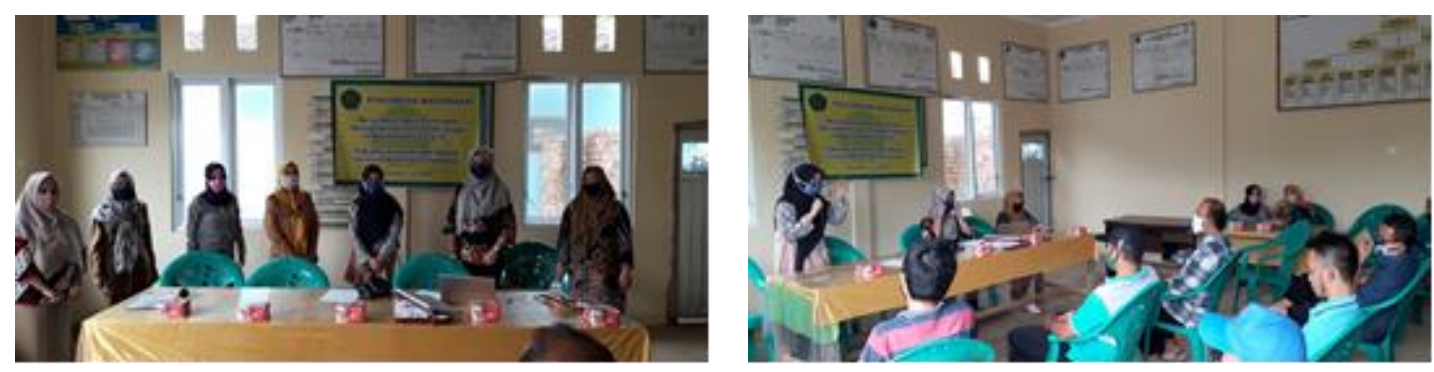

Gambar 1 Penyuluhan Pemanfaatan Media Sosial

Setiap instruktur menyampaikan materi dan membagikan slide materi agar seluruh peserta dapat menyimak materi pelatihan yang disampaikan. Materi pertama memaparkan mengenai perkembangan dari berbagai jenis perangkat mobile dan brand yang banyak digunakan dari tahun ke tahun. Selain itu juga dipaparkan mengenai manfaat kelebihan dan kekurngan dari penggunaan perangkat mobile. Materi kedua memaparkan mengenai aplikasi media sosial facebook yang dapat dijadikan sebagai media untuk memasarkan produk usaha menjadi lebih luas, karena dengan memanfaatkan media online produk yang dijual dapat diakses oleh pengguna lain lebih jauh jangkauannya, dan memudahkan penjual dan pembeli untuk dapat berkomunikasi dan berbagi informasi mengenai produk yang dipasarkan. Materi ketiga memaparkan mengenai aplikasi Shopee. Aplikasi Shopee merupakan aplikasi yang cocok digunakan oleh pengguna yang memiliki usaha bisnis secara online. Dengan penggunaan aplikasi tersebut pengguna yang memiliki usaha online dapat dengan mudah melakukan beberapa kegiatan yang berkaitan dengan bisnis online. Materi keempat membahas mengenai pengoptimalan penggunaan what's up dalam melakukan kegiatan penjualan dan pembelian.

Berdasarkan Rosyidi (2006) mengatakan bahwa pendapatan merupakan bentuk upah maupun gaji yang didapatkan sesuai dengan kinerja pekerja. Sehingga dari pendapatan tersebut dapat dikatakan sebagai modal untuk melangsungkan dan melengkapi kebutuhan sandang serta pangan kehidupan manusia (Situmeang, 2018). Sehingga masyarakat haruslah mampu meningkatkan kualitas keterampilan diri dengan mengikuti teknologi atau perkembangan zaman. Pendapatan tidak hanya 
didapatkan secara langsung namun melalui media online juga dapat meningkatkan pendapatan masyarakat (Aruni, Cangara, Arianto, 2019).

Dalam pelaksanaannya peserta mempraktikkan hasil implementasi yang telah dijelaskan dan dibuat sesuai dengan materi dipaparkan. Sebagian besar peserta antusias dalam mengikuti kegiatan pengabdian masyarakat. Hal itu dapat dilihat dari adanya banyak pertanyaan terkait dengan kegiatan. Selain itu peserta pada saat pelaksanaan pengabdian sudah memiliki banyangan mengenai produk apa yang dapat mereka jual serta aplikasi social media apa yang dapat mendukung penjualan mereka. Sehingga respon masyarakat tersebut merupakan cerminan dari kesadaran masyarakat tentang adanya kaitan erat antara media social dan tingkat pendapatan dan penjualan produk (Aruni, dkk 2019). Evaluasi langsung terhadap kegiatan ini juga dilakukan oleh peserta dimana peserta diminta untuk mengatakan tingkat pemahaman serta pendapat mereka mengenai kegiatan yang telah dilakukan khususnya dari materi yang disampaikan.

\section{KESIMPULAN DAN SARAN}

Mitra dalam kegiatan pengabdian masyarakat merupakan sekelompok warga dari Kelurahan Talang Keramat di Palembang. Kegiatan ini dilaksanakan untuk memberikan pelatihan kepada para peserta untuk mengoptimalkan penggunaan perangkat smartphone yang dimiliki dalam mendukung peluang bisnis di masa Pandemi Covid 19. Dalam pelaksanaannya seluruh kegiatan dilakukan secara offline dimulai dari kegiatan sosialisasi atau penyuluhan dengan membuatkan group whatsapp antara panitia dengan peserta, dilanjutkan pelatihan dengan menyampaikan materi dan proses terakhir dengan melakukan pendampingan peserta. Dari kegiatan yang dilakukan sebagian peserta merasakan manfaat dan ketertarikan yang lebih terhadap materi yang disampaikan. Hasil penilaian yang diperoleh menunjukkan bahwa dari sisi kepuasan peserta terhadap pelaksanaan kegiatan sangatbaik. Oleh karna itu adanya kerjasama yang baik dan kompak antara mitra dan instruktur pemakalah agar capaian kegiatan pengabdian masyarakat dapat maksimal.

\section{DAFTAR PUSTAKA}

Ayuni, Q., Cangara, H., Arianto (2019). Pengaruh Penggunaan Media Digital Terhadap Tingkat Penjualan Produk Kuliner Kemasan. Jurnal Penelitian Komunikasi dan Opini Publik. Vol 23 (2), hal 129-141.

Pabdi Forum. (2020). Kesiapan Kemenkes dalam Menghadapi Outbreak Novel Coronavirus. Kementrian kesehatan Republik Indonesia.

Purbohastuti, A. W. 2017. Efektifitas Media Sosial Sebagai Media Promosi. Jurnal Tirtayasa Ekonomika. Vol 12 (2), hal 212-231.

Rosyidi, Suherman. 2006. Pengantar Teori Ekonomi: Pendekatan Kepada Teori Ekonomi Mikro dan Makro. Jakarta: PT Raja GrafindoPersada.

Situmeang, R, R. (2018). Dampak Bisnis Online dan Lapangan Pekerjaan terhadap Peningkatan Pendapatan Masyarakat. Asian Journal of Innovation and Entrepreneurship. Vol 3 (3), hal 319-335.

Situmorang, J. R. (2012). Pemanfaatan Internet Sebagai New Media Dalam Bidang Politik, Bisnis, Pendidikan dan Sosial Budaya. Jurnal Administrasi Bisnis. Vol 8(1), hal 73-87. 
Warpindyastuti, L. D., \& Sulistyawati, M. E. (2018). Pemanfaatan Teknologi Internet Menggunakan Media Sosial Sebagai Sarana Penyebaran Informasi dan Promosi pada MIN 18 Jakarta. Jurnal Widya Cipta. Vol. 2(1).

Yuliana. (2020). Corona Virus Diseases (Covid-19): Sebuah Tinjauan Literature. Wellness and Healthy Magazine. Vol. 2(1), hal 187-192). 